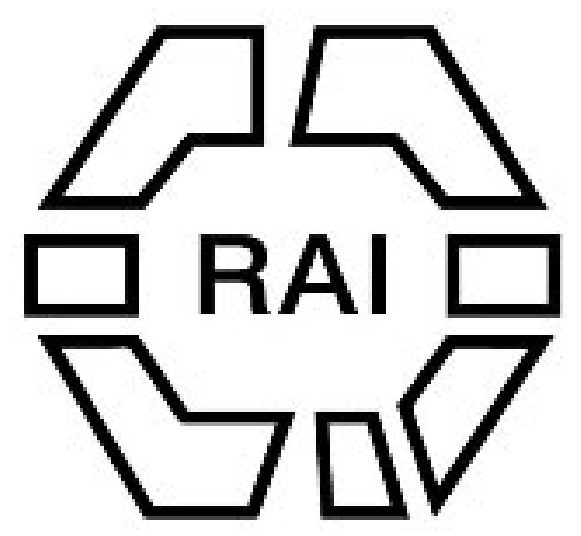

On the Relative Length of the First Three Toes of the Human Foot.

Author(s): J. Park Harrison

Source: The Journal of the Anthropological Institute of Great Britain and Ireland, Vol. 13 (1884), pp. 258-269

Published by: Royal Anthropological Institute of Great Britain and Ireland

Stable URL: http://www.jstor.org/stable/2841891

Accessed: 11/06/2014 10:28

Your use of the JSTOR archive indicates your acceptance of the Terms \& Conditions of Use, available at http://www.jstor.org/page/info/about/policies/terms.jsp

JSTOR is a not-for-profit service that helps scholars, researchers, and students discover, use, and build upon a wide range of content in a trusted digital archive. We use information technology and tools to increase productivity and facilitate new forms of scholarship. For more information about JSTOR, please contact support@ jstor.org.

Royal Anthropological Institute of Great Britain and Ireland is collaborating with JSTOR to digitize, preserve and extend access to The Journal of the Anthropological Institute of Great Britain and Ireland. 
ten, for which a term had been coined. Still lower in the scale of humanity were the races that could not count beyond two, and whose observation had been limited to the self as number one, and to everything else outside the self as number two, without any further subdivision. (3rd) As regards the degeneracy of tribes when they came in contact with a higher or a different form of civilisation than their own, this fact did not only apply to the savage Red Indians, but also to the cultured natives of India, whose indigenous civilisation, on which rested their moral, intellectual, and political life, was disappearing in consequence of the disintegrating processes of Anglicism.

The AUTHOR said, in reply to remarks which had made in the course of the discussion, that it would give him great pleasure to collect and send to the Institute such skulls and other relics of the aborigines as he might be able to obtain. He thought that many eminent Colombians would be ready to correspond with the Institute upon the subject of the paper, and he believed that Dr. Andres Posada Arango was a Member of the Anthropological Society of Paris. The belief in river and water-gods, to which Mr. Hyde Clarke had referred, was known to him, and existed outside the limits of the district to which the paper had reference, The Chibcha kingdom, where the Zipa was bathed in a lake after being powdered with gold dust, lay to the east of the Central Cordillera. The mineworkings certainly were of great interest, and he (Mr. White) had brought over from Colombia quite a representative set of stone implements, some rude and some highly finished, which the Indians used in the mines. These specimens were in the Christy collection. The mounds made by the Indians of the Dabeiba and Frontino district were circular, and were not like our barrows. In forming the vocabulary of Indian languages Mr. White made use of a system of interrogation given to him by Professor Bastian, of Berlin, very similar to that recommended by Dr. Leitner, but in spite of this there was always a great deal of difficulty in obtaining correct answers.

The following paper was then read by the author :-

\section{On the Relative Length of the First Three Toes of the Human Foot.}

By J. PArK Harrison, M.A.

IN a paper which I communicated to the Anthropological Department of the British Association at Southampton last year, I mentioned that a careful examination of the unrestored feet of Greek and Roman statues in various museums and galleries had led to the conviction that it was from Italy, and not Greece, 
that the long second toe affected by many English artists had been imported into this country.

As a fact, very few feet of statues executed in Greece itself exhibit the peculiarity, whilst in Italy, at the earliest period of Etruscan art, the foot is, as a rule, so represented. The suspicion consequently at once arose that a long second toe might prove to be racial, and so account for the proportions which the feature attained in the works of Raphael, ${ }^{1}$ and other great Italian masters, natives, possibly, of the districts in which the peculiar form of foot was most prevalent. Supposing a long toe to be racial, it would have appeared perfectly normal in their eyes, and inseparable from the forms adopted as their models.

That a long second toe is racial in Italy, though it may not characterise the Italians generally, has during the last year been more or less established by some observations made by a competent observer, at my request, in Tuscany, where both sculptors and painters represent the second toe as excessively long. Both at Florence, and the district between that city and Aosta, the peculiarity is said to be conspicuous in the barefooted inhabitants; and I am informed that it occurs in the feet of some of the Italian models employed at the Royal Academy of Arts, and in artists' private studios.

In order to ascertain whether the descendants of any of the races that form the population of the British Isles exhibited the peculiarity, an examination was made at Glasgow, in 1876 , of the feet of a large number of Scotch and Irish children, principally boys, between nine and thirteen years of age, who were then running about the streets of the city unshod. The result showed that the great toe was in all cases the longest; and the second never shorter than the third. The feet of several hundred children in Perthshire were also examined a few years later by Professor Flower, and not a single instance was met with of a short great toe. ${ }^{2}$ Similar results were obtained from observations made by myself at different times of children's feet in Dublin and the Irish quarters in London.

As opportunity offered, measurements were also procured of the feet of sailors, and other adult males in various country districts in the United Kingdom, and with few exceptions, and those almost exclusively in England, the great toe proved to be the longest. In no instance was the third or middle toe found to be longer than the second. ${ }^{3}$

1 See, for example, the sketches of feet in the Raphael Room at the British Museum; and compare them with the feet of the Choiseul Apollo, and the untouched cast of the only perfect foot of the Venus of Milos.

2 "Fashion in Deformity," p. 6 (note).

3 The details of the measurements referred to in the text were unfortunately lost in a railway train. 
Having heard that Sir James Paget had noticed, in the course of his extensive practice, that a long second toe was not uncommon, on my applying for information on the subject he obligingly undertook to make special observations for a month, and at the termination of that period furnished me with measurements of the feet of fifty persons, twenty-seven male and twenty-three female. ${ }^{1}$ In the case of the males, twenty-four out of the twentyseven had the first or great toe longer than (i.e., projecting beyond) the second; and in one case it was shorter than the second in the right foot, whilst in the left the first and second toes were of equal projection. In the remainder the difference was much the same in both feet.

In five instances the excess in the projection of the first or great toe beyond the second was about $\frac{1}{4}$ inch; and in one instance, a subject from Yorkshire, the excess was $\frac{1}{2}$ inch-in proportion, apparently, to the stature, viz., 6 feet 2 inches. The other five subjects were described as well formed, and two of them as tall. The minimum projection of the great toe was $\frac{1}{10}$ inch, and it occurred in the case of two children and three adults, two of whom were tall. In the foot of a Jew the first or great toe was $\frac{1}{8}$ inch longer than the second.

In the three instances in which the great toes were shorter than the second toes, one subject, aged nineteen, is described as tall, thin, and weakly; one, twenty-one years old, as well formed and athletic; and one, forty-six years old, as short and stout. In the first and last cases the deficiency was $\frac{1}{10}$ inch, and in the second $\frac{1}{8}$ inch.

There were six instances in which the second toe exceeded in length the third toe by $\frac{1}{4}$ inch; in two instances the difference was $\frac{1}{12}$ inch; and in one instance the second and third toes were of equal length.

No instance occurred of a third toe that was longer than the second.

In the case of the female feet, in ten out of twenty-three subjects the first or great toe was longest, and in ten females it was shorter than the second toe. In the remaining three instances the first and second toes were of equal length. On tabulating the observations, however, according to age (see Tables I and II), by far the greater number of longer second toes were found to belong to women above thirty years of age. The maximum excess in the second toe was $\frac{1}{3}$ inch, in a subject aged forty-five, described as tall and well formed. In two instances the second toe exceeded the first in length by $\frac{1}{4}$ inch;

1 They were eye-measurements, liut Sir J. Paget informs me they may be relied on as correctly estimated. 
both subjects, aged eighteen and fifty-one respectively, were well formed, and one of them tall. In five subjects the excess in length of the second toe over the first was $\frac{1}{8}$ inch.

The maximum excess in length of the great toe was $\frac{1}{3}$ inch, and it occurred in the case of two subjects, both of whom are described as tall and well formed. The minimum excess was $\frac{1}{8}$ inch, and it occurred in three instances; two of the subjects were tall and well formed.

There were two instances in which the second toe exceeded the third toe in length by $\frac{1}{4}$ inch, and one instance in which the excess was $\frac{1}{3}$ inch. The subjects were tall. The minimum excess in projection of the second toe over the third in adults was $\frac{1}{10}$ inch, and it occurred in three cases.

Two of the subjects with longer great toes were of Greek origin.

TABLE I.

Male Feet.

\begin{tabular}{|c|c|c|c|c|}
\hline Age. & $\begin{array}{l}\text { Great toe } \\
\text { longest. }\end{array}$ & $\begin{array}{l}\text { Great toe } \\
\text { shorter } \\
\text { than } \\
\text { second. }\end{array}$ & $\begin{array}{l}\text { Second toe } \\
\text { longer } \\
\text { than third. }\end{array}$ & Observations. \\
\hline $\begin{array}{c}\text { Years. } \\
\mathbf{2} \\
\mathbf{3} \\
\mathbf{9} \\
\mathbf{1 2} \\
\mathbf{1 4} \\
\mathbf{1 4} \\
\mathbf{1 9} \\
\mathbf{2 1} \\
\mathbf{2 5} \\
\mathbf{2 6} \\
\mathbf{2 8} \\
30 \\
40 \\
\mathbf{4 3} \\
\mathbf{4 6} \\
\mathbf{4 8} \\
\mathbf{4 9} \\
\mathbf{5 0} \\
\mathbf{5 3} \\
\mathbf{5 4} \\
\mathbf{5 5} \\
60 \\
\mathbf{6 1} \\
65 \\
69 \\
\mathbf{7 0} \\
80\end{array}$ & $\begin{array}{c}\text { inch. } \\
\frac{1}{10} \\
\frac{1}{8} \\
\frac{1}{10} \\
\frac{1}{4} \\
\frac{1}{6} \\
\frac{1}{8} \\
\cdots \\
\because \\
\frac{1}{3} \\
\frac{1}{2} \\
\frac{1}{8} \\
\frac{2}{3} \\
\frac{1}{8} \\
\frac{1}{8} \\
\frac{1}{10} \\
\frac{1}{10} \\
\frac{1}{6} \\
\frac{1}{10} \\
\frac{1}{8} \\
\frac{1}{4} \\
\frac{1}{4} \\
\frac{1}{10} \\
\frac{1}{6} \\
\frac{1}{4} \\
\frac{1}{8} \\
\frac{1}{8} \\
\frac{1}{6}\end{array}$ & 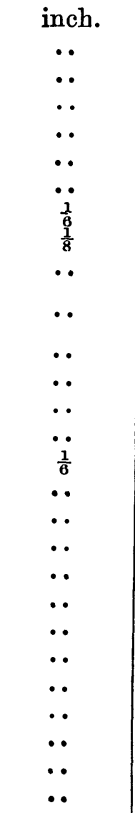 & $\begin{array}{c}\text { inch. } \\
\frac{1}{10} \\
\frac{1}{8} \\
\frac{1}{10} \\
\frac{1}{3} \\
\frac{1}{4} \\
\frac{1}{10} \\
\frac{1}{8} \\
\frac{1}{8} \\
\frac{1}{4} \\
\frac{1}{4} \\
\frac{1}{4} \\
\frac{1}{4} \\
\frac{1}{6} \\
\frac{1}{8} \\
\frac{1}{6} \\
=\frac{1}{8} \\
\frac{1}{8} \\
\frac{1}{12} \\
\frac{1}{6} \\
\frac{1}{8} \\
\frac{1}{8} \\
\frac{1}{3} \\
\frac{1}{8} \\
\frac{1}{4} \\
\frac{1}{12} \\
\frac{1}{6} \\
\frac{1}{8}\end{array}$ & $\begin{array}{l}\text { Well formed. } \\
\text { Slight ; ricketty. } \\
\text { Small and feeble. } \\
\text { From Yorkshire; good foot. } \\
\text { Rather flat and long feet. } \\
\text { Well formed. } \\
\text { Tall ; thin; weakly. } \\
\text { Well formed; athletic. } \\
\text { Tall ; thin. } \\
\text { } 6 \text { ft. } 2 \text { in. ; strong; from } \\
\text { Yorkshire. } \\
\text { Tall; well formed. } \\
\text { Well made. } \\
\text { Well formed. } \\
\text { Short; stout. } \\
\text { Average size. } \\
\text { Tall ; well formed. } \\
\text { Tall; well formed. } \\
\text { Jew ; well formed. } \\
\text { Well formed. } \\
\text { Tall ; well formed. } \\
\text { Tall; well formed. } \\
\text { Tall; well formed. } \\
\text { Well formed. } \\
\text { Tall; thin. } \\
\text { Well formed. } \\
6 \text { ft. ; good foot ; toes parallel. }\end{array}$ \\
\hline
\end{tabular}


TABLE II.-Female FeeT.

\begin{tabular}{|c|c|c|c|c|}
\hline Age. & $\begin{array}{l}\text { Great toe } \\
\text { longer } \\
\text { than } \\
\text { second. }\end{array}$ & $\begin{array}{c}\text { Great toe } \\
\text { shorter } \\
\text { than } \\
\text { second. }\end{array}$ & $\begin{array}{c}\text { Second toe } \\
\text { longer } \\
\text { than third. }\end{array}$ & Observations. \\
\hline $\begin{array}{c}\text { Years. } \\
4 \\
4 \\
\mathbf{1 6} \\
\mathbf{1 7} \\
\mathbf{1 8} \\
20 \\
24 \\
\mathbf{2 4} \\
\mathbf{3 0} \\
\mathbf{3 0} \\
\mathbf{3 5} \\
\mathbf{3 6} \\
\mathbf{4 5} \\
\mathbf{4 8} \\
\mathbf{5 0} \\
\mathbf{5 1} \\
\mathbf{5 2} \\
\mathbf{5 3} \\
\mathbf{5 4} \\
\mathbf{5 4} \\
\mathbf{5 4} \\
\mathbf{6 3} \\
\mathbf{6 7}\end{array}$ & 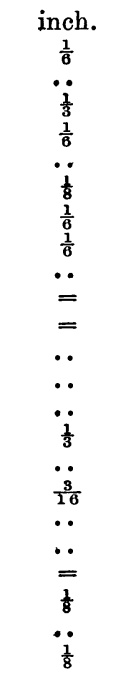 & 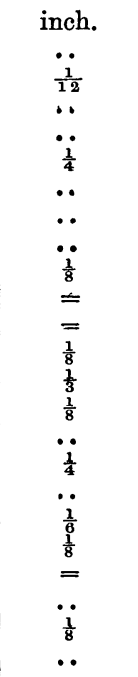 & $\begin{array}{l}\text { inch. } \\
\frac{1}{12} \\
\frac{1}{12} \\
= \\
\frac{1}{8} \\
\frac{1}{6} \\
\frac{1}{10} \\
\frac{1}{8} \\
\frac{1}{8} \\
= \\
\frac{1}{10} \\
\frac{1}{8} \\
\frac{1}{8} \\
\frac{1}{4} \\
\frac{1}{1} \\
\frac{3}{18} \\
\frac{1}{3} \\
=\frac{1}{8} \\
\frac{1}{8} \\
\frac{1}{8} \\
\frac{1}{8} \\
\frac{1}{6} \\
\frac{1}{8} \\
\frac{1}{10}\end{array}$ & $\begin{array}{l}\text { Slight ; ricketty. } \\
\text { Left foot; right deformed. } \\
\text { Tall ; well formed. } \\
\text { Greek ; thin. } \\
\text { Well formed. } \\
\text { Half Greek. } \\
\text { Irish ; } 6 \text { ft. } \\
\text { Well formed. } \\
\text { Well formed. } \\
\text { Well formed. } \\
\text { Well formed. } \\
\text { Tall ; well formed. } \\
\text { Tall ; stout. } \\
\text { Tall ; well formed. } \\
\text { Tall ; well formed. } \\
\text { Well formed. } \\
\text { Well formed. } \\
\text { Short ; stout. } \\
\text { Tall ; well formed. } \\
\text { Welsh ; tall ; robust. } \\
\text { Tall ; well formed. }\end{array}$ \\
\hline
\end{tabular}

The sign $=$ implies that the lengths of the first and second toes, or of the second and third, are equal.

Sir James Paget forwarded, with his own observations, some results obtained in the suburbs of London by Mr. E. G. Gilbert, M.R.C.S., mainly from measurements taken under his directions. Of 164 persons, of both sexes and of all ages, 115 were found to have the first or great toe longer than the second, and in eight cases the first and second were of equal length. In forty cases the second toe was reported to be longer than the great toe; and in one case the great toe was longer than the second in one foot, and shorter in the other. In every instance where the feet of more than one member of the same family were examined, Mr. Gilbert says, they were found to be of the same form. In one group or set of observations, the number of instances in which the first toe was shorter than the second was reported to be considerably greater in females than in males.

Mr. Gilbert has since procured further information regarding the latter observations.

The female subjects alluded to were pupils in a training college for school teachers, and on a careful examination of the feet of those in residence, who were returned on the previous 
occasion as having a short great toe, or have been found to possess it on subsequently joining the college, Mr. Gilbert has ascertained that there are six whose second toe is longer than the first, and three whose first and second toes are of equal length, out of a total of thirty-three. There is also one student with the second toe longest out of a total of twenty-one male pupils. The difference was not more than $\frac{1}{16}$ inch in any instance.

Owing to the fact that the parents of the students were mostly either Londoners or inhabitants of large towns, their racial origin could not be ascertained with any certainty, though Mr. Gilbert took notes which it was hoped might assist in doing so. In three cases, however, there appears to have been a very close resemblance between the subjects: the hair is described as dark; the eyes hazel; the nose not arched, the lips full. The average stature did not exceed 5 feet $1 \frac{1}{2}$ inches. One was a native of the Isle of Wight. The parents of the other two belonged to Sheffield, Westbury, and London. In these three cases the first and second toes were of equal length. With the exception of the female student, who belonged to Sheffield, all the pupils with longer second toes were born in southern towns; and none of them exhibited any Celtic characteristics.

The occurrence of a long second toe in the higher and upper middle classes, at an age when it might be expected that the continued use of narrow and straight-soled shoes would cause a chronic eversion of the great toe, might perhaps have sufficiently accounted for some of the cases of a shorter great toe in Table II, had the numbers been sufficient to justify the induction. "Rights and lefts," which it appears were not invented much before the middle of the century, prevent much eversion of the great toe in male feet; but they are not, it is believed, made use of by women, except in a shape that is little efficacious.

To ascertain whether the feet of Scotch women exhibited any change in form after thirty, application was made to Professor Struthers, of Aberdeen, for information on the subject, when he at once sent me ten observations, in nine of which the great toe proved to be longest. The following are the ages, and the projections of the toes alluded to :-

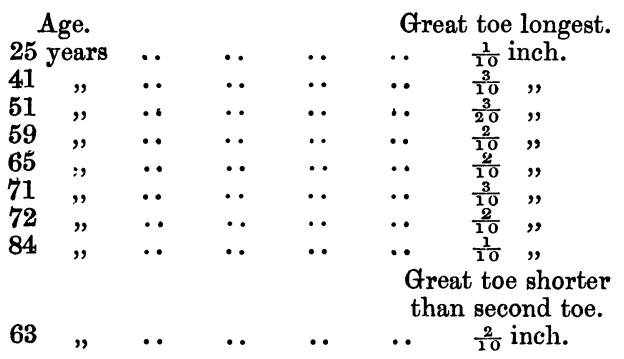


In this last case, Professor Struthers measured the projection of the third toe as well as the first and second, when it was found to be $\frac{4}{10}$ inch shorter than the second. ${ }^{1}$ This, and some other cases of the same kind, seem to indicate that the difference in length between the first and second toes may be occasionally due to an abnormal growth of the second, and not to any defect in length of the great toe.

In connexion with the question of race or heredity, it will be pertinent to mention that Dr. Pruner found that a longer second toe characterised the feet of Alsatian women, and so, by implication, not of French women generally; and it is not so in the only two skeleton feet of French women that I have measured, one of them included in Table III. ${ }^{2}$ It may prove to be a nonCeltic peculiarity, as we have seen that it is almost invariably absent in Scotch and Irish feet, and so far as is at present ascertained in the Welsh foot also.

The opportunity which was afforded by the late exhibition of twenty Zulus at Westminster was taken advantage of to examine the form of their feet. It resulted in the somewhat unexpected discovery that no tendency existed amongst them to a long second toe. There appeared, however, to be more variability in the length of toes in the two feet than occurs in the case of Europeans; and their fourth and fifth toes were well developed, not having been stunted in their growth by shoes.

In about half the subjects, the difference in the length of the first and second toes was the same in both feet. In seven instances the difference in length of the first and second toes was least in the right foot; and in three instances it was greater.

In five instances the difference in the length of the first and second toes reached or exceeded $\frac{1}{2}$ inch in favour of the first or great toe of the right foot; and in six instances it occurred in the left foot. The minimum excess in length of the great toe was $\frac{1}{16}$ inch, and it occurred in three subjects in the right foot. The minimum in the case of the left foot was $\frac{1}{8}$ inch, and it occurred twice. In one instance the two toes of the right foot were equal, whilst the difference in the left was $\frac{1}{8}$ inch in favour of the great toe.

In five instances the difference in length of the second and third toes was the same in both feet. In six instances it was as much as $\frac{5}{10}$ inch in favour of the second over the third, in the case

1 Some measurements of skeleton feet in the Anatomical Museum at Aberdeen were forwarded with these measurements ; and the first toe in two female feet, presumably Scotch, as the preparations were made at Aberdeen, was in each case longer than the second (see Table IV).

${ }_{2}$ In the Natural History Museum at Oxford there are two French skeletons, in the smaller of which, apparently female, the second toe is considerably longer than the first; but the second phalanx has evidently been restored. 
of the right foot, and in four instances in the left. The minimum excess of length in the second toe over the third was $\frac{1}{8}$ inch, and it occurred once in the case of the right foot, and twice in the case of the left.

From tracings made by Mr. George W. Bloxom, F.L.S. (Assistant Secretary of the Anthropological Institute), of the feet of the four Waganda envoys who visited this country three years ago, it appears that the difference in the length of their first and second toes was, in two instances, $\frac{1}{2} \frac{1}{0}$ inch in favour of the first or great toe, the second toe in both cases being quite $\frac{5}{10}$ inch longer than the third, and this in both feet alike. In the other two subjects, the excess in length of the great toe was $\frac{5}{10}$ inch; the second toe was $\frac{5}{10}$ inch longer than the third in one case, and $\frac{3}{10}$ inch in the other case, and this, too, in both feet. 1

These results were also unexpected.

Dr.Pruner, in a "Memoire sur les Négres," quoted by Dr. Hunt, in a note to his paper on the "Negro's Place in Nature," says that " it is true that the great toe of the Negro rarely rises above the second, but neither is it often shorter." But " a slight shortening of the great toe undoubtedly exists, not merely amongst the Negro tribes, but also in ancient and modern Egyptians, and even in some of the most beautiful races of Caucasian females."

The existence of a longer second toe in the Boschmen, and some tribes on the Congo, \&c., ${ }^{3}$ amongst whom it appears to be racial, is important, as possibly connecting them, and more especially the former people, with the Egyptian dark race. Professor Rolleston, it will be remembered, came to the conclusion, from craniological evidence, that the Boschmen were descended from ancestors in a high state of civilisation; and it is remarkable that their representations of cows and other animals closely resemble, in outline and colour, frescoes in Egyptian tombs.

From my own observations the feet of the Botocudo Indians were found to have the second toe shorter than the first.

Skeleton feet in various museums have been carefully examined, and in many cases found to be sufficiently well articulated to allow of measurernents being taken of the projection of the phalanges ; and, generally speaking, no difficulty was experienced in detecting restorations, principally from the difference in colour and substance of the bones. In England, moreover, the practice

1 The measurements being derived from tracings of the feet, may not in all cases be reliable, but they may be taken as fairly correct.

2 "Mem. Anthrop. Soc.," vol. i, p. 6 (note).

3 Judging from the feet of skeletons at Paris. 
of mending and completing imperfect specimens is seldom resorted to, though it is common in France, and has to be specially guarded against in preparations imported from that country.

The skeleton great toes of the following savage or semi-civilised races are found to be shorter than the second toes:--Peruvians, Tahitians, New Hebrideans, Savage Islanders, Ainos, and New Caledonians-all inhabiting islands in the Pacific, or the Indian Ocean, with the exception of the Peruvians, who, however, it has long been suspected, may have reached America by sea from the West, at a date signalised by their knowledge of art: and they are thought to have left footmarks on their way. In another direction the peculiar feature appears to characterise one of the races in India.

In the following tables, the difference in excess in the projection (1) of the great toe, and (2) of the second over the first, in skeletons in the Museum of the Royal College of Surgeons, is given in tenths of an inch in the first column of fractions : and the excess in the projection of the second toe over the third is shown in the column adjoining. The skeleton feet in which first and second toes are equal in length are separately tabulated (3). The numbers in the first column are those of the skeletons in the museum. Excepting when absent or defective, the measurements of the toes of the right foot only are inserted. Where, however, the difference between them amounted to $\frac{2}{10}$ inch, the projection is given for both feet. An asterisk indicates that a phalanx is doubtful. The measurements from Aberdeen will be found in Table IV.

TABLE III.-SKeLEToN FeET.

(1)

\begin{tabular}{|c|c|c|c|c|c|c|}
\hline No. & Sex. & First toe lo & & & Inch. & Inch. \\
\hline $\begin{array}{c}67 \\
69 \\
70 \\
71 \\
223 \\
224 \\
1043 \\
1068 \text { A } \\
1096 \\
2288 \\
1398 \\
1406\end{array}$ & $\begin{array}{l}\text { M. } \\
\text { M. } \\
\text { F. } \\
\text { M. } \\
\text { M. } \\
\text { M. } \\
\text { F. } \\
\text { M. } \\
\text { M. } \\
\text { F. } \\
\text { F. } \\
\text { M. } \\
\text { M: } \\
\text { F. }\end{array}$ & 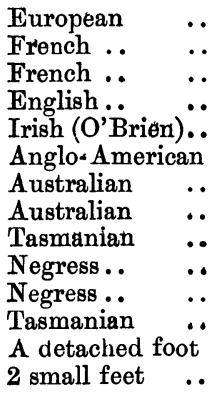 & $\begin{array}{l}\ddot{.} \\
\ddot{.} \\
\ddot{.} \\
\ddot{.} \\
\ddot{.} \\
\ddot{.} \\
\ddot{.} \\
\ddot{.}\end{array}$ & 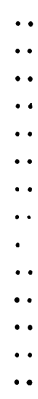 & $\begin{array}{l}\frac{1}{10} \\
\frac{1}{10} \\
\frac{3}{10} \\
\frac{1}{20} \\
\frac{6}{10} \\
\frac{3}{10} \\
\frac{1}{20} \\
\frac{1}{20} \\
\frac{1}{20} \\
1 . \frac{1}{10} \\
\frac{2}{10} \\
\frac{1}{20} \\
\frac{1}{10} \\
\frac{1}{10}\end{array}$ & $\begin{array}{l}\frac{5}{10} \\
\frac{6}{10} \\
\frac{4}{10} \\
\frac{4}{10} \\
\frac{5}{10} \\
\frac{3}{10} \\
\frac{1}{10} \\
\frac{1}{10} \\
\frac{3}{10} \\
\frac{3}{10} \\
\frac{3}{10} \\
\frac{4}{10} \\
\frac{1}{10} \\
\frac{2}{10}\end{array}$ \\
\hline
\end{tabular}


(2)

\begin{tabular}{|c|c|c|c|c|c|c|c|}
\hline No. & Sex. & \multicolumn{4}{|c|}{ Second toe longest. ${ }^{1}$} & Inch. & Inch. \\
\hline 54 & M. & European & -. & .. & .. & $\frac{1}{10}$ & $\frac{2}{10}$ \\
\hline 338 & M. & European & .. & .. & .. & $\frac{1}{10}$ & $\begin{array}{l}\text { r. } \frac{2}{10} * \\
1 .-4\end{array}$ \\
\hline $\begin{array}{l}582 \\
583 \\
757 \\
800 \\
847 \\
897\end{array}$ & $\begin{array}{l}\text { M. } \\
\text { M. } \\
\text { M. } \\
\text { M. } \\
\text { F. } \\
\text { M. }\end{array}$ & $\begin{array}{l}\text { Sikh .. } \\
\text { Egyptian } \\
\text { Savage Island } \\
\text { Tahitian } \\
\text { Aino .. } \\
\text { Javanese }\end{array}$ & $\begin{array}{l}\ldots \\
\ddot{p} \\
\ldots \\
\ddot{0} \\
.\end{array}$ & $\begin{array}{l}\ldots \\
\cdots \\
\cdots \\
\cdots \\
\ldots\end{array}$ & $\begin{array}{l}. . \\
\ldots \\
\ldots \\
\ldots \\
\ldots\end{array}$ & $\begin{array}{l}\frac{2}{10} \\
\frac{1}{20} \\
\frac{3}{10} \\
\frac{3}{10} \\
\frac{1}{10} \\
\frac{1}{10}\end{array}$ & $\begin{array}{l}\frac{1}{10} \\
\frac{2}{10} \\
\frac{2}{10} \\
\frac{1}{10} \\
\frac{1}{10}\end{array}$ \\
\hline 898 & F. & Javanese & .. & .. & .. & $\frac{3}{10}$ & r. $\frac{4}{10}$ \\
\hline $\begin{array}{l}1014 \\
1278 \\
1239 \\
1283 \\
1301\end{array}$ & $\begin{array}{l}\text { F. } \\
\text { M. } \\
\text { M. } \\
\text { F. }\end{array}$ & $\begin{array}{l}\text { Peruvian.. } \\
\text { Peruvian } \\
\text { North Americ } \\
\text { Andamanese } \\
\text { Boschman }\end{array}$ & $\begin{array}{l}\ddot{ } \\
\ddot{a n} \\
\ddot{0} \\
\ddot{.}\end{array}$ & $\begin{array}{l}. \\
\ddot{a} \\
\ddot{a} \\
\ddot{a}\end{array}$ & $\begin{array}{l}\ddot{.} \\
\ddot{.} \\
\ddot{.}\end{array}$ & $\begin{aligned} \frac{1}{10} \\
\frac{1}{20} \\
\frac{1}{20} \\
\text { l. } \frac{1}{10} \\
\frac{2}{10}\end{aligned}$ & $\begin{array}{l}\frac{10}{10} \\
\frac{1}{10} \\
\frac{2}{10} \\
\frac{1}{10} \\
\frac{2}{10}\end{array}$ \\
\hline 1438 & M. & New Hebridea & & .. & .. & $\left\{\begin{array}{l}\frac{2}{10} \\
\frac{4}{4} *\end{array}\right.$ & $\frac{3}{10}$ \\
\hline $\begin{array}{r}1472 \\
797\end{array}$ & & $\begin{array}{l}\text { Andamanese } \\
\text { Bhutea.. }\end{array}$ & $\ddot{. .}$ & $\ddot{.}$ & .. & $\frac{\frac{1}{20}}{\frac{1}{10}}$ & $\begin{array}{l}\frac{1}{8} \\
\frac{1}{10}\end{array}$ \\
\hline
\end{tabular}

(3)

\begin{tabular}{|c|c|c|c|c|c|c|c|}
\hline No. & Sex. & \multicolumn{4}{|c|}{ First and second toes equal. } & Inch. & Inch. \\
\hline $\begin{array}{r}684 \\
1013 \\
1219 \\
63 \AA\end{array}$ & $\begin{array}{l}\text { M. } \\
\text { F. } \\
\text { M. } \\
\text { F. }\end{array}$ & $\begin{array}{l}\text { Samoyede } \\
\text { Peruvian } \\
\text { African.. } \\
\text { Girl's foot }\end{array}$ & $\begin{array}{l}\ldots \\
\cdots \\
\cdots\end{array}$ & $\begin{array}{l}\ddot{ } \\
\ddot{*} \\
\ddot{*}\end{array}$ & $\begin{array}{l}. \\
\ddot{.} \\
. .\end{array}$ & $\begin{array}{l}= \\
= \\
= \\
=\end{array}$ & $\begin{array}{l}\frac{3}{10} \\
\frac{1}{4}\end{array}$ \\
\hline
\end{tabular}

TABLE IV.

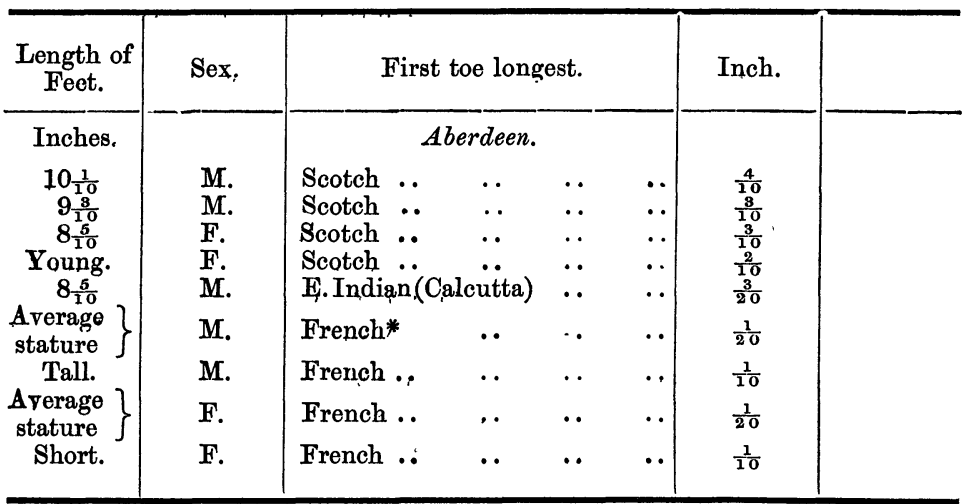

1088 F. Australian Feet imperfectly prepared. 
To facilitate the conversion of the fractions of the English inch into French measures, the following equivalents are given. It will be easy to arrive at other values by simple multiplication or division, as the case may require :-

$$
\begin{aligned}
& 1 \text { inch }=2.500 \text { centimètres. } \\
& \frac{1}{3} "=0.833 \quad " \\
& \frac{1}{4} "=0.625 \quad " \\
& \frac{1}{8} "=0.312 \quad, \\
& \frac{1}{10} "=0.250 \quad,
\end{aligned}
$$

In the Physiological Room at the Royal College of Surgeons there are fifteen foetuses, of ages between three and six months of intra-uterine life (numbered 3666 to 3681 ), the feet of which are in a position to allow of eye-observation being made. Eleven have the first toe longer than the second; and in three cases the length of the first and second toes appear to be equal. In one case the second toe is longer than the first. Eight of the examples are male, and seven are female.

It should be added, that from photographs, as well as the reports of competent observers, it appears that the great toe in the Basque foot is longer than the second. This agrees with the results of measurements of several feet of the small dark Welshmen, who are supposed, with good reason, to represent the race in this country.

On the other hand, the second toe of the descendants of the Carians and Lysians of Asia Minor is reported to be longer than the first. If this should eventually be found to be so, it would be important in connection with the longer second toe of the Etruscans, who are believed to have been allied in blood with the above people.

In this and other cases further information is required; and it is hoped that travellers will record the projection of the toes of the foot for the future, amongst their other anthropological notes. In the present paper little has been done beyond ascertaining that a long second toe does not characterise the inhabitants of this country.

The result sufficiently accords with the views of Holden, who, in his "Human Osteology," states that the great toe is longer than the second; and of Professor Flower, who believes that it characterises the European foot generally. In Professor Humphry's "Human Skeleton," the first or great toe is represented as the longest; and this is also the case in two French works of authority, the first, "Le Corps Humain," illustrated with designs from nature by Edouard Cuer; and the other, "L'Anatomie Artistique," by Duval.

In Professor J. Marshall's “ Anatomy for Artists," however, the accomplished author lays it down, as a rule, that the second toe 
in a well-formed foot is slightly longer than the great toe, but that in a number of instances the great toe islongest. "Numerous observations," he says, seem to indicate that the conditions in which the great toe is the longest occur more frequently in persons of tall stature, or slender frame, whilst shorter or more stoutly built individuals usually have the great toe shorter than the second." Professor Marshall believes with the majority of artists that it was the practice of the Greeks so to represent it, and it seems to be generally believed that it was an ideal form derived from Egyptian art.

This, I think there is evidence to show, was not the case; although the form of toe existed in one of the early races in Egypt, and in Italy, and was copied from nature in the works of art in those countries.

As regards the art question, although this is not the occasion to enlarge upon it, it may be mentioned that a model foot, according to Flaxman, is one in which the toes follow each other imperceptibly in a graceful curve, from the first or great toe to the fifth. This does not appear to differ much from Professor Marshall's canon if rigidly interpreted. Unfortunately, however, the illustrations of the phalanges in the "Anatomy for Artists" represent the second toe as considerably longer than the first; and most of the casts of feet in our Art schools are derived either from Roman models or restored Greek feet, as, for example, the left foot of the Farnese Apollo, and the (Roman) copy of the Discobolus in the British Museum. In both cases the second toe of the left foot is a good deal longer than the first. In the cast of a marble foot attributed to Praxiteles, the second toe is slightly longer than the first, but it is ill-formed, and appears to have been copied from nature. It has not been taken as a guide in the restoration of the Hermes (to which it is supposed to belong) at present placed beside it. Two marble feet in one of the Parthenon cases have longer great toes.

Professor Flower has remarked that a long great toe is essentially human $;^{1}$. and certainly whenever it is conspicuously shorter than the second, and the second much longer than the third, it gives the foot an animalesque appearance.

\section{Discussion.}

Mr. HiLton PrICE remarked that he was inclined to believe that the ancient Egyptians had the second toe longer than the first; it was of course well known in sculptures; but he had the foot of a mummy with the second toe longer than the first.

1 "Fashion in Deformity," p. 6 (note). 